\title{
New records of the rare benthopelagic genera Comantenna Wilson, 1924 and Crassantenna Cole, Green, Howcroft et Rawlins, 1972 (Copepoda: Calanoida: Aetideidae) from the North Pacific abyss
}

\author{
Первые находки редких бентопелагических родов Сотаntenna \\ Wilson, 1924 и Crassantenna Cole, Green, Howcroft et Rawlins, 1972 \\ (Copepoda: Calanoida: Aetideidae) из абиссали северной Паџифики
}

\author{
Elena L. Markhaseva ${ }^{1}$, J.M. Bradford-Grieve ${ }^{2}$, J. Renz ${ }^{3}$

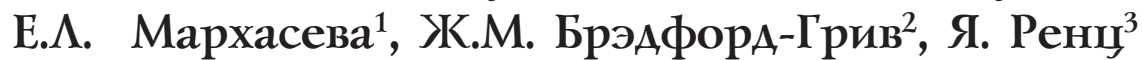

\footnotetext{
' Zoological Institute, Russian Academy of Sciences, Universitetskaya nab. 1, St. Petersburg 199034, Russia. E-mail: markhaseva@yahoo.com

1 Зоологический институт РАН, Университетская наб. 1, Санкт-Петербург 199034, Россия.

${ }^{2}$ National Institute of Water and Atmospheric Research, Private Bag 14901, Wellington 6241, New Zealand

${ }^{3}$ Senckenberg Research Institute, German Center for Marine Biodiversity Research (DZMB), Martin-Luther-King Platz 3, D-20146 Hamburg, Germany
}

KEY WORDS: Copepoda, Calanoida, Comantenna, Crassantenna, benthopelagic, North Pacific, abyss.

КЛЮЧЕВЫЕ СЛОВА: Copepoda, Calanoida, Comantenna, Crassantenna, бентопелагический, северная Пацифика, абиссаль.

ABSTRACT. Rare benthopelagic aetideid copepods Crassantenna comosa Bradford, 1969 and Comantenna crassa Bradford, 1969, previously known only from their holotypes off New Zealand, South $\mathrm{Pa}$ cific, are found for the first time in the abyss in the vicinity of the Kurile Kamchatka Trench, North Pacific. Minor morphological differences were observed between the North and South Pacific specimens of both species. Evidence of intraspecific variability was observed among the 31 specimens of $C$. crassa: spermathecae were bent at various obtuse angles, there was variability in the degree of fusion of antennule ancestral segments IV-VII; the maxilliped coxal sensory appendage had a range of lengths, and the P5 was present or absent. The genus Crassantenna, as $\mathrm{Cr}$. comosa, is recorded for the first time in the northern part of the Pacific Ocean and minor differences from the holotype are assumed to represent intraspecific variation until more specimens are examined for evidence of variability.

РЕЗЮМЕ. Редкие виды веслоногих рачков аетидеид Crassantenna comosa Bradford, 1969 и Comantenna crassa Bradford, 1969, ранее известные только по голотипам из южной Пацифики из района Новой Зеландии, впервые найдены в северной Пацифике в непосредственной близости от дна в абиссали Курило-Камчатского желоба. У обоих видов отмечены небольшие морфологические различия между экземплярами из южной и северной Пацифики. Внутривидовая изменчивость наблюдается и среди курило-камчатских представителей $C$. crassa (31 экземпляр) и заключается в следующем: сперматеки изогнуты под разными углами; в различной степени слиты анцестральные сегменты антеннул IV-VII; сенсорный придаток на коксе максиллипеды варьирует по длине, а Р5 присутствует или отсутствует. Род Crassantenna впервые найден в северной части Тихого океана и представлен видом $C r$. comosa, который слегка отличен по строению от голотипа, однако, пока не появятся дополнительные материалы, эти отличия сочтены проявлением внутривидовой изменчивости.

\section{Introduction}

One female of Crassantenna comosa Bradford, 1969 and 31 females of Comantenna crassa Bradford, 1969 were sorted from deep-water samples collected from the near-bottom environment of the Kurile Kamchatka Trench area. Specimens were described and compared with their types deposited in New Zealand, Wellington [Bradford, 1969].

Both species were previously known only from their holotypes and represent rare benthopelagic aetideid genera that contain few species, so far known from a few individuals.

The genus Comantenna Wilson, 1924 includes five species. Comantenna recurvata Grice et Hulsemann, 1970 and C. curtisetosa Alvarez, 1986 were recorded from the Atlantic Ocean. C. brevicornis (Sars, 1902) was collected in the northeastern Atlantic, off the Norwegian coast and off the Barents and North Seas, and C. gesinae Schulz, 2002 is known from the Weddell 
Sea [Sars, 1902; Vervoort, 1952; Grice, Hülsemann, 1970; Alvarez, 1986; Markhaseva, 1996; Schulz, 2002]. C. crassa is the only representative of the genus recorded from the southwestern Pacific Ocean, off New Zealand [Bradford, 1969].

The genus Crassantenna Cole, Green, Howcroft et Rawlins, 1972 includes two species, Cr. comosa and Cr. mimorostrata Bradford, 1969, that, until recently, have been found nowhere else except from the southwestern Pacific [Bradford, 1969].

The discovery of C. crassa and Cr. comosa outside their type localities $\left(34-37^{\circ} \mathrm{S} 174-177^{\circ} \mathrm{E}\right)$ represents the first record of these species from the North Pacific, while the genus Comantenna has been previously recorded from the North Pacific [Ohtsuka et al., 2005].

The significant number of individuals (31) obtained from the samples enabled the investigation of intraspecific variation in $C$. crassa. The close relationship of C. crassa to C. recurvata was previously noted [Alvarez, 1986; Schulz, 2002] as well as their similar depth preferences. Comantenna crassa, $C$. recurvata and $C$. curtisetosa share a lower slope and abyssal plains habitat, while their remaining congeners $(C$. brevicornis and $C$. gesinae) are shallow water species [Bradford, 1969; Grice, Hülsemann, 1970; Alvarez, 1986; Markhaseva, 1996; Schulz, 2002].

\section{Material and methods}

Benthopelagic calanoid copepods of the genera $\mathrm{Co}$ mantenna (31 females) and Crassantenna (one female) were collected by the RV Sonne during the KuramBio (Kurile Kamchatka Biodiversity Study) expedition using an epibenthic sledge [Brenke, 2005]. Samples were collected in July 21 - September 7, 2012 in the vicinity of the sea bed in the abyss of the North Pacific between $40-46^{\circ} \mathrm{N} 148-155^{\circ} \mathrm{E}$ at depths from 4859 to $5399 \mathrm{~m}$. Individuals were present in both, the supranet (sampling layer ca. $0.77-1.12 \mathrm{~m}$ above the bottom) and the epinet subsamples $(0.25-0.60 \mathrm{~m}$ above the bottom).

Specimens from KuramBio were stained by adding a solution of chlorazol black E dissolved in 70\% ethanol $/ 30 \%$ water. Oral parts and swimming legs were dissected, mounted in glycerin and figured using a camera lucida.

Holotypes of Cr. comosa and C. crassa deposited in the National Institute of Water and Atmospheric Research (NIWA, earlier NZOI [Bradford, 1969]) were re-examined by Janet Bradford-Grieve.

The following abbreviations are used in the descriptions: P1-P5, legs 1-5; Exp, exopod; Enp, endopod. Free segments of the antennule are designated by Arabic numerals, ancestral segments by Roman numerals. One seta and one aesthetask on a segment of the antennule are designated: $1 \mathrm{~s}+1 \mathrm{ae}$, " 1 ?" indicates that a setal element was broken so that its identity on the antennule could not be determined and only the scar at the location of its attachment was counted. The numbering of the ancestral segments of the antennule fol- lows Huys \& Boxshall [1991]. The terminology for oral parts follows Markhaseva \& Ferrari [2006] and Ferrari \& Ivanenko [2008] and is as compiled in Markhaseva et al. [2014].

\section{Taxonomy}

Family Aetideidae Giesbrecht, 1893

Genus Comantenna Wilson, 1924

Comantenna crassa Bradford, 1969

Figs 1-2.

MATERIAL. 31 adult $\$ \circ$, two CV collected: Sta. 2-10 on 3.08.2012 from $46^{\circ} 14.77^{\prime} \mathrm{N} 155^{\circ} 32.79^{\prime} \mathrm{E}$, at depths $4859-4865 \mathrm{~m}$ (2 OO$^{\circ}$ ); Sta. $5-10$ on 11.08 .2012 from $43^{\circ} 34.44^{\prime} \mathrm{N} 153^{\circ} 58.06^{\prime} \mathrm{E}$ at depths $5375-5378$ ( 2 우); Sta. $7-10$ on 17.08 .2012 from $43^{\circ} 01.82^{\prime} \mathrm{N}$ $152^{\circ} 58.55^{\prime} \mathrm{E}$ at depths $5223-5221 \mathrm{~m}$ (4 90 , of them 2 with P5, $1 \mathrm{CV}$ ); 2 우 (of them 1 with P5), Sta. $8-12$ on 21.08.2012 from $42^{\circ} 14.38^{\prime} \mathrm{N} 151^{\circ} 43.12^{\prime} \mathrm{E}$ at depths $5127-5124 \mathrm{~m}$ (2 0 , 1 with $\mathrm{P} 5)$; Sta. $9-12$ on 24.08 .2012 from $40^{\circ} 34.49^{\prime} \mathrm{N} 150^{\circ} 59.85^{\prime} \mathrm{E}$ at depths 5399-5392 mm (4 90 , of them 3 with P5, 1CV); Sta. 10-12 on 27.08 .2012 from $41^{\circ} 12.80^{\prime} \mathrm{N} 150^{\circ} 05.61^{\prime} \mathrm{E}$ at depths $5245-5262$ $\mathrm{m}$ (16 우, 3 with P5); Sta. $11-12$ on 31.08 .2012 from $40^{\circ} 12.32^{\prime} \mathrm{N}$ $148^{\circ} 05.73^{\prime} \mathrm{E}$ at depths $5350-5348 \mathrm{~m}(1+)$ and + , holotype (NIWA1038 or H58)

Total length of 26 adult females measured: 1 specimen $(3.10 \mathrm{~mm}), 3$ specimens $(3.20 \mathrm{~mm}), 3$ specimens $(3.30 \mathrm{~mm}), 5$ specimens $(3.35 \mathrm{~mm}), 5$ specimens $(3.40$ $\mathrm{mm}), 2$ specimens $(3.45 \mathrm{~mm}), 7$ specimens $(3.50 \mathrm{~mm})$.

DESCRIPTION. Adult female, total length 3.10$3.50 \mathrm{~mm}$ (holotype $3.80 \mathrm{~mm}$ ); prosome $3.05-4.2$ times as long as urosome. Cephalosome and pediger 1 partly fused (holotype) or fused, pedigers 4 and 5 separate; posterior corners of prosome upturned dorsally (Fig. 1A-F). Genital double-somite with spermathecae directed dorsoanteriorly, bent at midlength at various obtuse angles (Fig. 1B-F), spermathecae not visible in ventral view (Fig. 1G). Rostrum absent (Fig. 1B). Caudal rami with 4 terminal (III-VI), 1 ventral (VII), and 2 dorsolateral (I-II) setae (Fig. 2A).

Antennules (Fig. 1H-J) reaching to middle of pedigerous somite 2 , or to posterior part of pedigerous somite 3; of 21 free segments. Ancestral segments IIVII usually fused although signs of demarcation between segments IV-V, V-VI and VI-VII evident and segments X-XI and XXVII-XXVIII also fused. Armature as follows: I-1s, II-IV-6s, V-1s+1ae, aesthetasc long with an oval tip, VI to IX-2s each, X-XI-4s, XII to XXI-2s each, XXII to XXIII-1s each, XXIV to XXVI-2s each, XXVII-XXVIII-5s + 1ae.

Antenna (Fig. 2B-C), coxa with 1 seta, basis with 2 setae, first endopod segment longer than exopod, with 1 seta, second with $8+7$ setae; exopod indistinctly 6segmented, setal formula $0,[0-0-1-1], 1,1,1,[0-3]$; terminal exopod segment nearly as long as 2 preceding segments, with 3 setae, 1 seta significantly shorter than the other two setae.

Mandible, basis with 2 setae, exopod 5-segmented, with 1, 1, 1, 1, 2 setae; endopod segment 1 with 1 seta, segment 2 with 4-5 setae. 

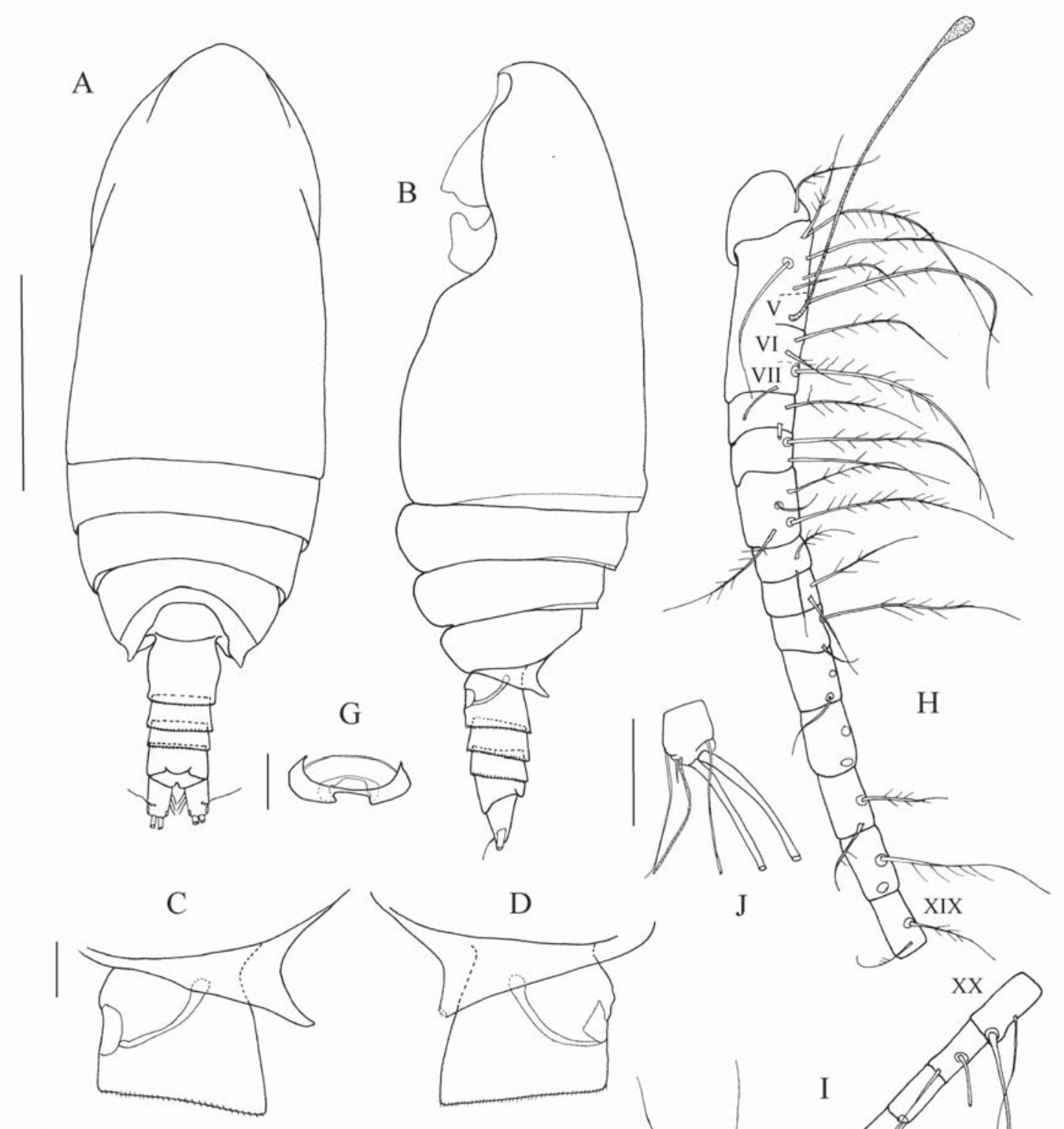

$\mathrm{H}$
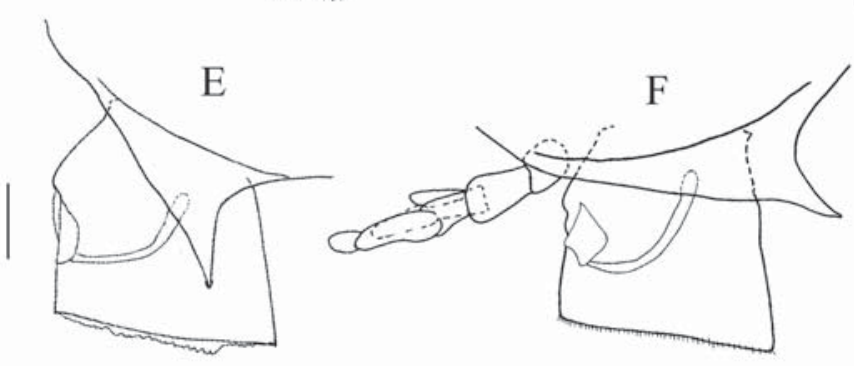

$\mathrm{J}$

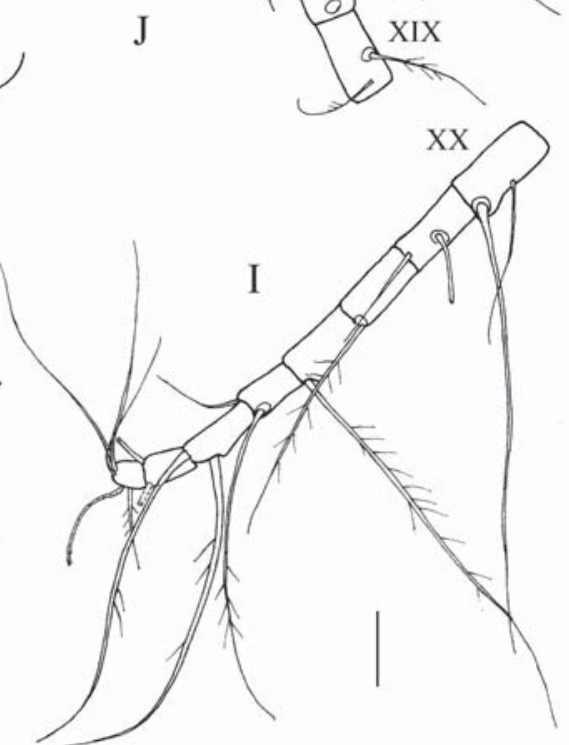

Fig. 1. Comantenna crassa. Female: A - habitus, dorsal view; B - habitus, lateral view; C, D, E, F - posterior prosome and genital double-somite, lateral view; $\mathrm{G}$ - genital field, ventral view; $\mathrm{H}$ - right antennule, ancestral segments I-XIX; I - right antennule, ancestral segments XX-XXVIII; J - antennule, ancestral segments XXVII-XXVIII. A-D, H-I - specimen from Sta. 2-10; E-G, J - specimens from Sta. 10-12. Scales bars for A-B $-1 \mathrm{~mm}$, remaining figures $-0.1 \mathrm{~mm}$.

Рис. 1. Comantenna crassa. Самка: А - общий вид дорсально; В - общий вид латерально; C, D, E, F — задние углы просомы и генитальный сегмент латерально; G - генитальное поле вентрально; Н - правая антеннула, анцестральные сегменты I-XIX; I - правая антеннула, анцестральные сегменты XX-XXVIII; J — антеннула, анцестральные сегменты XXVII-XXVIII. A-D, H-I экземпляр со станции 2-10; E-G, J - экземпляры со станции 10-12. Масштаб: А-B - 1 мм, остальные рисунки - 0,1 мм. 


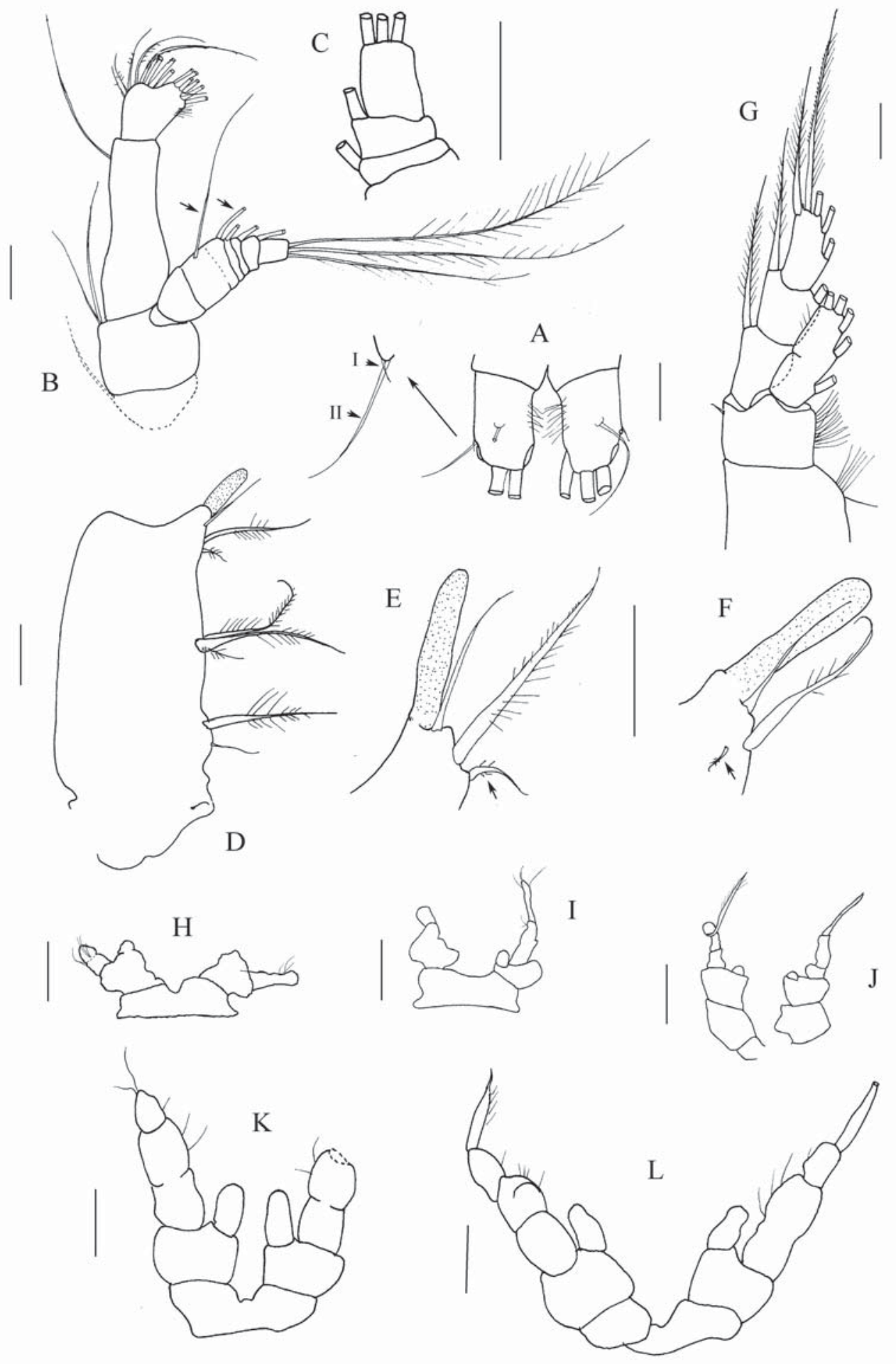

Fig. 2. Comantenna crassa. Female: A - caudal rami, ventral view; B - antenna, two proximal setae marked by arrows, coxa indicated by dotted line added after another specimen; $\mathrm{C}$ - antenna, three terminal exopod segments; D - maxilliped, syncoxa; E, F maxilliped coxa, distal setae and sensory appendage, arrows mark proximalmost seta. G - P1; H - L, P5. A, K - specimens from Sta. 10-12; B-D, G - specimens from Sta. 2-10; H-I, L - specimens from Sta. 9-12; F, J, specimens from Sta. 8-12. Scale bars $0.1 \mathrm{~mm}$.

Рис. 2. Comantenna crassa. Самка: А - каудальные ветви вентрально; В - антенна первая и вторая проксимальные щетинки помечены стрелками, отмечена пунктиром кокса дорисованная по другому экземпляру; $\mathrm{C}$ - антенна, три терминальных сегмента экзоподита; D - максиллипеда, синкокса; Е, F — максиллипеда, кокса, дистальные щетинки и сенсорный придаток; G - P1; H L, P5.A, K - экземпляры со станции Sta. 10-12; B-D, G - экземпляры со станции 2-10; H-I, L - экземпляры со станции 9-12; F, $\mathrm{J}$ - экземпляры со станции 8-12. Масштаб 0,1 мм. 


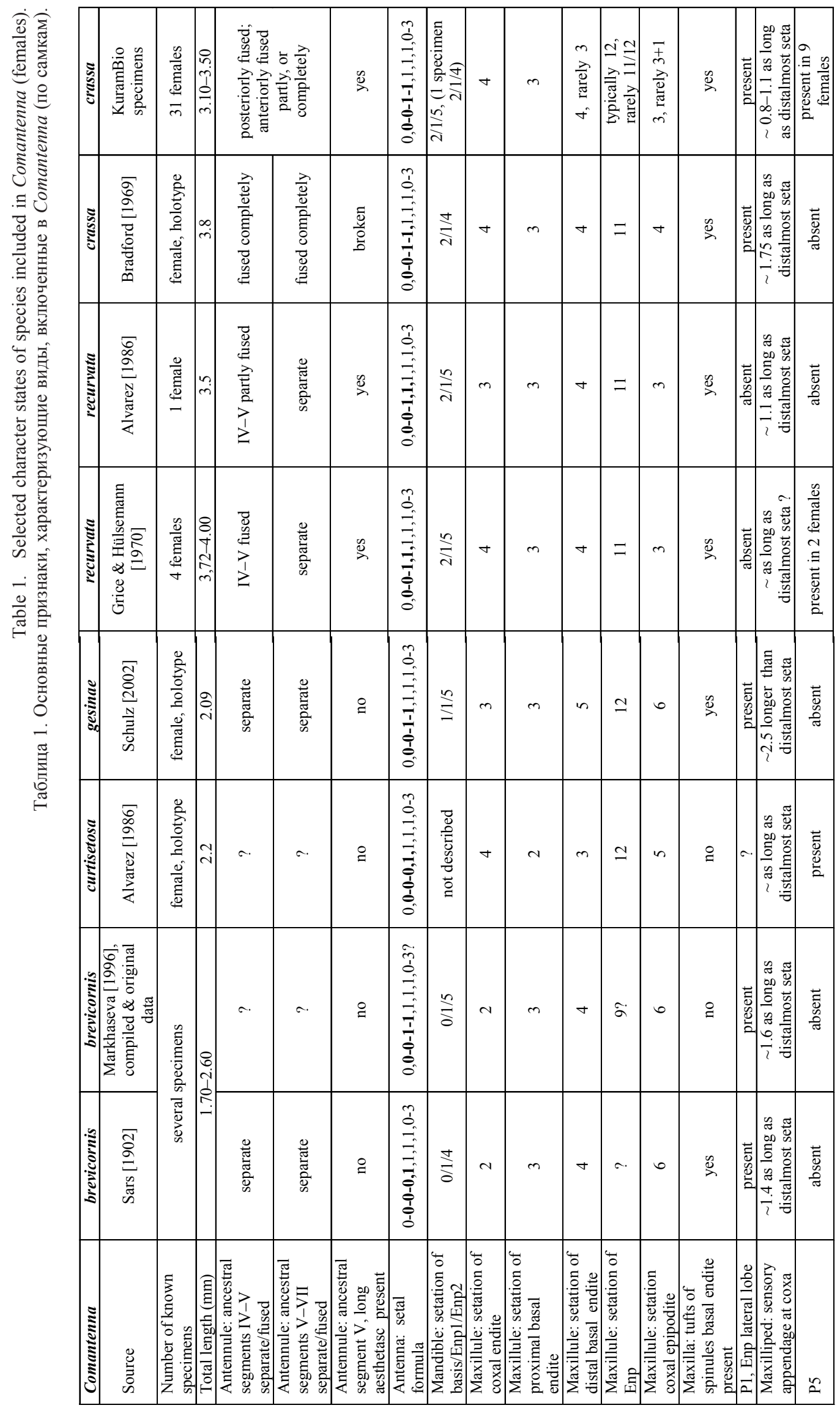


Maxillule, praecoxal arthrite with 9 terminal, 4 posterior and 1 anterior setae; coxal endite with 4 setae, proximal basal endite with 3 setae and distal basal endite with 4 (rarely 3 ) setae; endopod with 12 (rarely 11 setae); exopod with 11 setae; coxal epipodite with 3 (rarely 4) setae.

Maxilla, all endites with 3 setal elements; praecoxal to basal endites with tufts of spinules; endopod with 6 setae.

Maxilliped (Fig. 2D-F), praecoxal endites of syncoxa with 1, 2 and 3 setae (from proximal to distal); coxal endite of syncoxa with 3 setae, sensory appendage varies in length from about 0.8 to 1.1 as long as the distalmost coxal seta, coxal proximalmost seta 0.1 to 0.5 as long as coxal plumose/middle seta; basis with 3 medial setae; endopod with 2, 4, 4, 3, 3+1, and 4 setae.

P1 (Fig. 2G), coxa without seta; basis with very small distolateral seta, medial distal seta absent; endopod 1-segmented, lateral lobe developed; exopod segments 1,2, and 3 with 1 lateral spine each; lateral spine of exopod segment 1 extending to mid-length of exopod segment 2 lateral spine, lateral spine of exopod segment 2 reaching nearly to mid-length of the exopod segment 3 lateral spine.

P2-P4 typical for genus, coxa with medial seta; basis without seta; endopod 2-segmented in P2, 3segmented in P3-P4; all exopods 3-segmented; coxa of $\mathrm{P} 2$ and $\mathrm{P} 3$ rarely with patch of spinules lateroproximally.

P5 (Fig. 2H-L), absent or present; when present, varies in size and configuration, asymmetrical, uni- or biramous; coxa and basis without setae; endopod 1segmented or absent; exopod 1-3 segmented.

REMARKS. KuramBio Comantenna specimens have been attributed to the species $C$. crassa, which description was based on a moderately damaged single female holotype with antennule, antenna, maxilliped and legs possessing some segments and setae broken or missing [Bradford, 1969; Bradford, Jillet, 1980]. While damage to the holotype makes its complete comparison with KuramBio specimens impossible, further taxonomic analysis reveals KuramBio specimens to share the general features of C. crassa as updated from reexamination of the holotype by one of us (JB-G).

The KuramBio specimens and the holotype differ in the following minor details: 1) their smaller size (3.1-3.50 mm vs $3.8 \mathrm{~mm}$ holotype); 2) the cephalosome and pediger somite 1 are fused (vs partly fused in the holotype); 3 ) the spermathecae narrow or expanded anteriorly (narrow in the holotype); 4) the antennule ancestral segment XIV short terminal seta is not broad at its base (vs seta seems to be distinctively broad in holotype); 5) the maxilliped distal sensory appendage about $0.8-1.1$ as long as the distalmost coxal seta (vs sensory appendage definitely longer in the holotype), and 6) the maxilliped distal praecoxal endite is smooth (supplied by small denticles in the holotype). These differences are here regarded as reflecting intraspecific variation as the range of this variation is similar to morphological variations among KuramBio specimens.
The KuramBio specimens show a considerable variability in: 1) the curvature of the spermathecae: at its midlength it is bent at different obtuse angles in most specimens (Fig. 1C-F), and the spermathecae can be differently bent on the left and on the right in the same specimen (Fig. 1C-D); 2) the degree of fusion between antennal ancestral segments IV-VII (segments IV-V can be fused completely or incompletely; V-VI and VI-VII can be fused, incompletely fused, or separate, see also Table $1 ; 3$ ) the maxilliped coxal sensory appendage varies in length from 0.8 to 1.1 times as long as the distalmost coxal seta (Fig. 2D-F and see Fig. 70 in Bradford [1969] and Table 1; 4). The maxilliped coxal proximalmost seta varies from 0.1 to 0.5 times as long as the coxal plumose middle seta (Fig. 2D-F); 5) the P5 is absent or present (in 9 specimens), when present, then of various configurations (Fig. 2H-L).

The presence or absence of the P5 was not found to be associated with variability of the posterior prosomal corners, spermathecae, oral parts or legs.

Comantenna crassa is closely related to C. recurvata and it was once suggested that $C$. recurvata might be a synonym of $C$. crassa [Bradford, Jillet, 1980], but was retained as a separate species by Alvarez [1986] and Schulz [2002]. Both species share the following characters (Table 1): 1) body length more than $3 \mathrm{~mm}$ (vs $2.60 \mathrm{~mm}$, or less in congeners); 2) antennule ancestral segment $\mathrm{V}$ bears a long aesthetasc with an oval tip, segments IV and V partly or completely fused (vs long aesthetasc absent and segments IV and V separate in congeners); 3) mandibular basis with 2 setae (vs 1 seta in congeners); 4) combination of setae at the maxillule coxal, proximal and distal basal endites respectively as: 3-4, 3, and 3-4 (vs 2, 3 and 4 in C. brevicornis; 4, 2 and 3 in C. curtisetosa, and 3, 3 and 5 in C. gesinae, see Table 1), and 5) maxillule coxal epipodite with 3-4 setae (vs 5-6 setae in congeners).

Neverthelesss, Comantenna crassa may be distinguished from $C$. recurvata by: 1) antennule ancestral segments V-VII partly or completely fused anteriorly and completely fused posteriorly (vs segments separate in $C$. recurvata) and 2) $\mathrm{P} 1$ endopod lateral lobe is developed (vs lateral lobe absent in C. recurvata).

Genus Crassantenna Cole, Green, Howcroft et Rawlins, 1972

Crassantenna comosa Bradford, 1969 Figs 3-4.

MATERIAL. One adult + , Sta. $1-10$ on 30.07 .12 from $43^{\circ}$ $58.44^{\prime} \mathrm{N} 157^{\circ} 18.29^{\prime} \mathrm{E}$, at depths $5418-5419 \mathrm{~m}$, and female, holotype (NIWA1047 or H63).

DESCRIPTION. Adult female, total length 3.70 $\mathrm{mm}$ (KuramBio specimen and holotype); prosome 3.6 as long as urosome. Cephalosome and pediger 1 partly fused, pedigers 4 and 5 fused dorsally (holotype), or partly fused (KuramBio specimen); posterior corners of prosome slightly upturned dorsally (Fig. 3A), reaching posterior third of genital double-somite, shorter in 


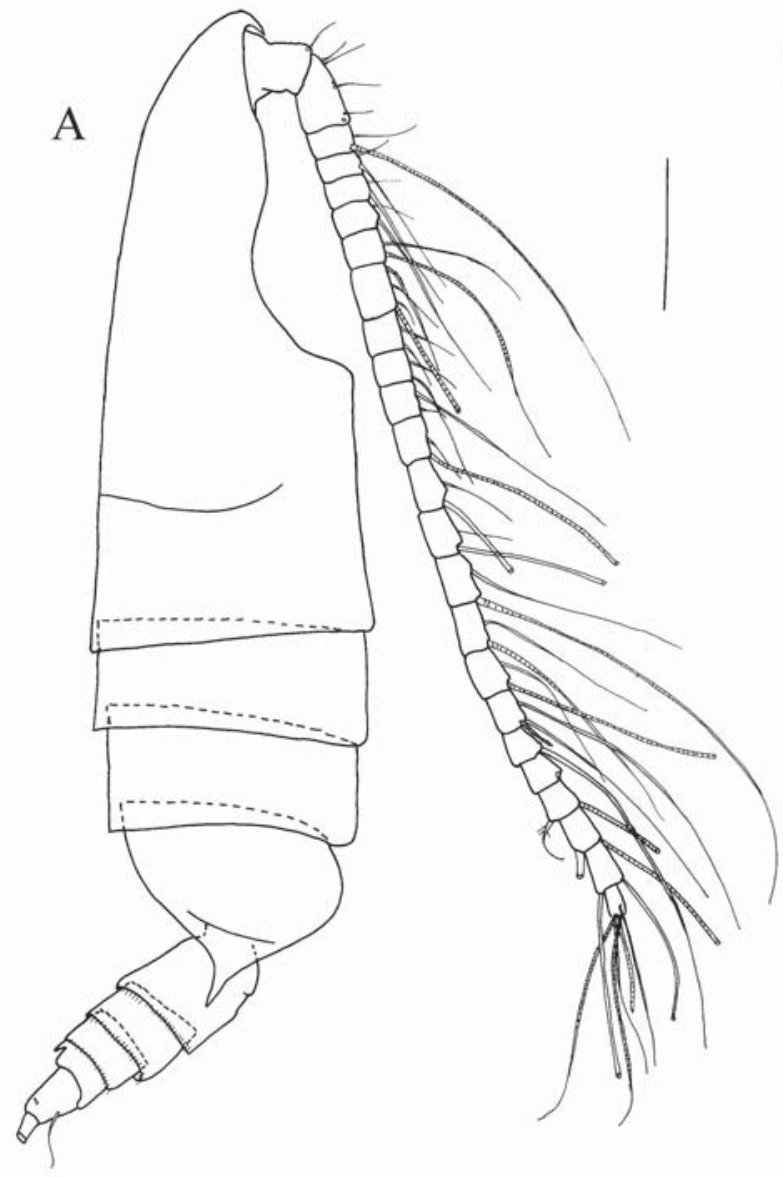

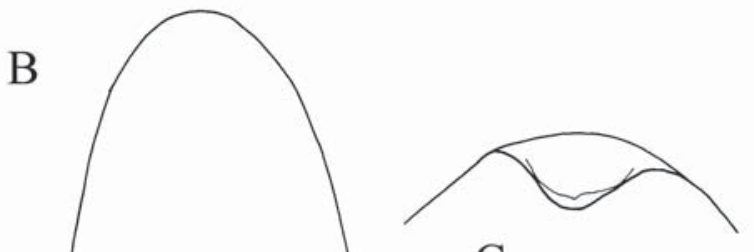

$\mathrm{C}$

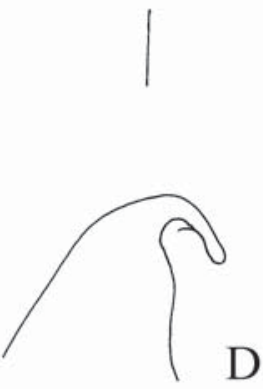

E

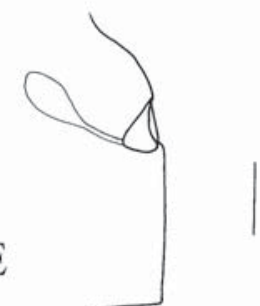

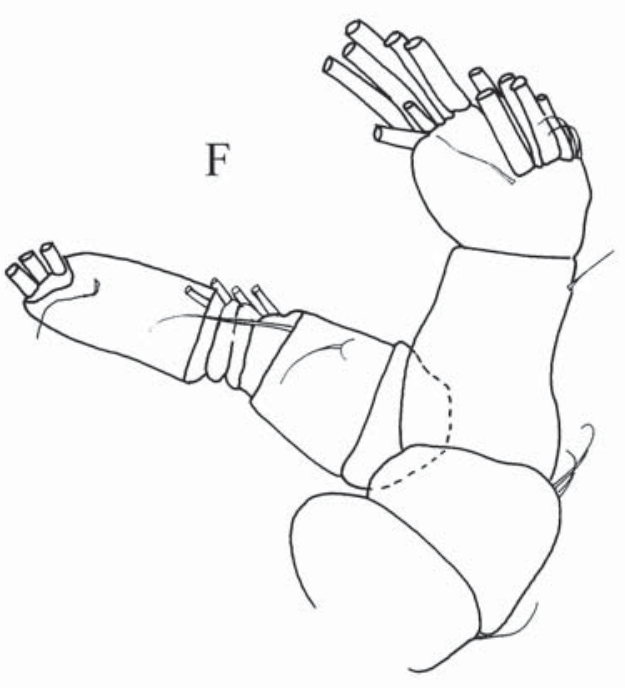

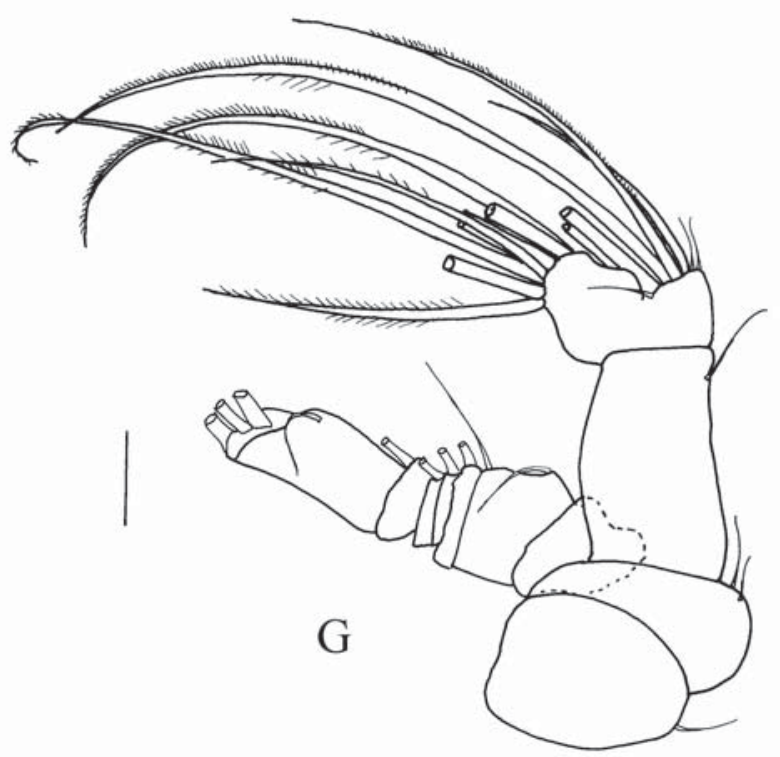

Fig. 3. Crassantenna comosa. Female: A - habitus, lateral view; B - habitus, dorsal view; C, D - rostrum in dorsal and lateral views; E - genital double-somite, lateral view of ventral part; F, G - antenna, different views. Specimen from Sta. 1-11. Scales bars for $\mathrm{A}-\mathrm{B}-0.5 \mathrm{~mm}$, remaining figures $-0.1 \mathrm{~mm}$.

Рис. 3. Crassantenna comosa. Самка: А - общий вид латерально; В - общий вид дорсально; С, D - рострум; Е генитальный сегмент, брюшная часть латерально; F, G - антенна, вид с разных позиций. Экземпляр со станции 1-11. Масштаб: A-B - 0,5 мм, остальные рисунки - 0,1 мм. 


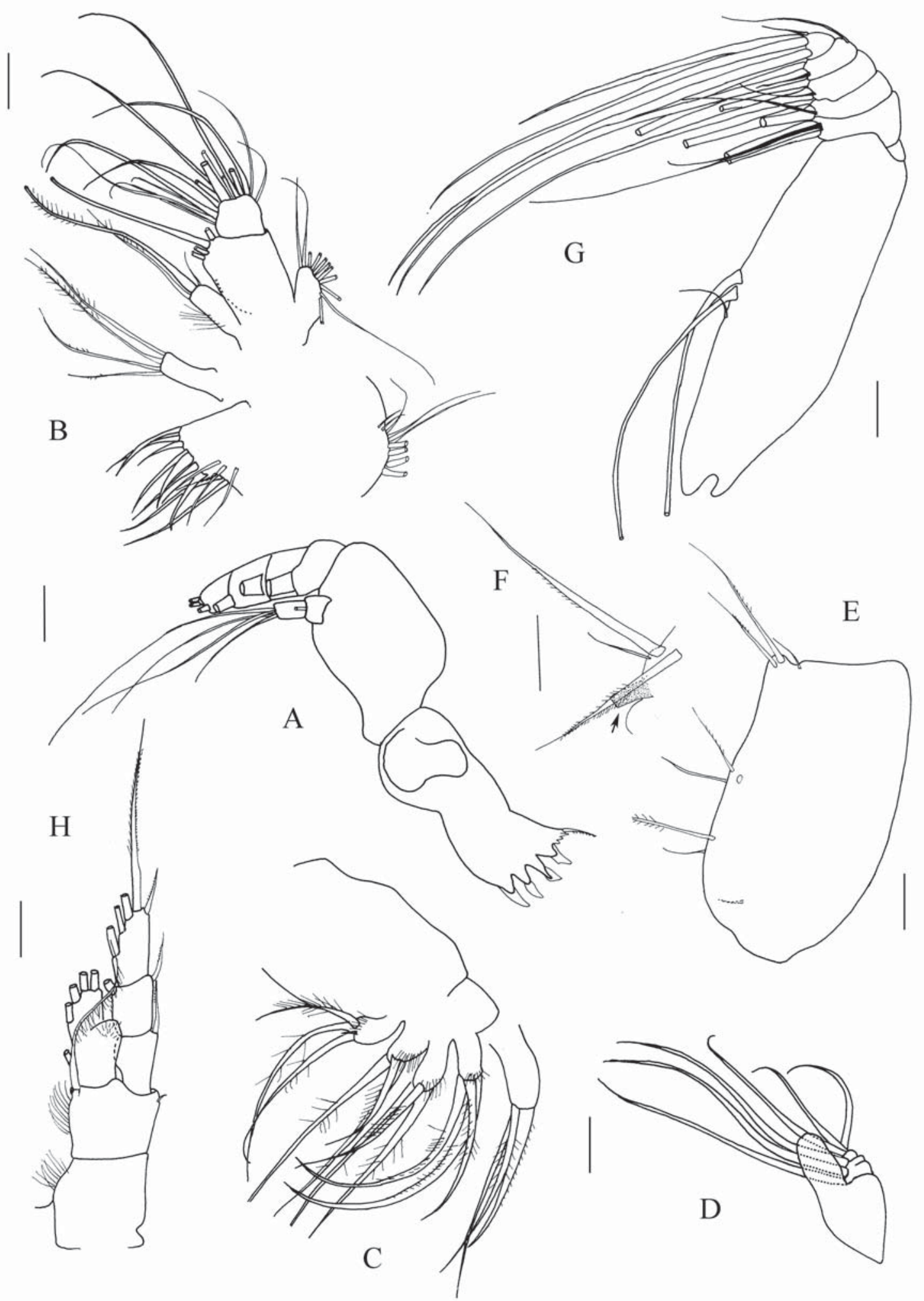

Fig. 4. Crassantenna comosa. Female: A - mandible; B - maxillule; C - maxilla without endopod; D - endopod of maxilla; E maxilliped, syncoxa; F - maxilliped coxa with sensory appendage marked by arrow; G - maxilliped basis and endopod; H P1.Specimen from Sta. 1-11. Scales bars $0.1 \mathrm{~mm}$.

Fig. 4. Crassantenna comosa. Самка: А - мандибула; В - максиллула; C - максилла без эндоподита; D - эндоподит максиллы; E - максиллипеда, синкокса; F — кокса максиллипеды с сенсорныи придатком, обозначен стрелкой; $\mathrm{G}$ - максиллипеда, базис и эндоподит; Н - Р1. Экземпляр со станции 1-11. Масштаб: 0,1 мм. 
holotype; posterior corners of prosome in dorsal view pressed close to genital double-somite (Fig. 3B), but not as close and shorter in holotype. Genital doublesomite with spermathecae directed dorsoanteriorly, with oval distal part (Fig. 3E). Rostrum represented by blunt plate (Fig. 3C-D). Caudal rami with 4 terminal, 1 ventral, and 1 dorsolateral setae, setae either broken or represented by scar at the location of insertion.

Antennules (Fig. 3A) reaching pedigerous somite 5, of 24 free segments, armature as follows: I-1s, II-IV $4 \mathrm{~s}+2$ ?, V to IX-2s each, X-XI-4s, XII to XX-2s each, XXI-2s+1ae (ae also present in holotype), XXII to XXIII-1s each, XXIV to XXVI-2s each, XXVIIXXVIII-4s + 1ae (aesthetasc also present in holotype); setae mostly pseudoannulate and not plumose.

Antenna (Fig. 3F-G), coxa with 1 seta, basis with 2 setae, exopod slightly longer than endopod, setation formula as $0,0-1-1,1,1,1,1,1,3$; endopod segments wide, wider, than exopod; endopod segment 1 with 1 seta, segment 2 with 7 large outer terminal setae (6 in holotype) and 8 inner subterminal setae (1 shorter, 2 inner setae very small).

Mandible (Fig. 4A), basis without seta, exopod 5segmented, with $1,1,1,1$, and 2 setae; endopod segment 1 with 1 seta, segment 2 with 4 setae; gnathobase with 7 teeth, 3 small (in holotype these are sharp and narrow and almost as long as other teeth and, adjacent to the base of articulated seta, long setules are situated at base of 3 sharp teeth).

Maxillule (Fig. 4B), praecoxal arthrite with 9 terminal, 3 (2 setae in holotype) posterior and 1 anterior setae; coxal endite with 4 setae, proximal basal endite with 3 ( 2 setae in holotype) and distal basal endite with 4 setae; endopod with 15 (4, 3 and 8 seta in holotype, segments 2 and 3 separate); exopod with 11 setae; coxal epipodite with 7 long plus 2 short setae (damaged in holotype, small setae not visible).

Maxilla (Fig. 4C-D), all endites with 3 setal elements; praecoxal to basal endites with tufts of spinules; endopod with 6 setae.

Maxilliped (Fig. 4E-G), praecoxal endites of syncoxa with 1, 2 and 3 setae (from proximal to distal, proximal seta broken in holotype); coxal endite of syncoxa with 3 setae and sensory appendage visible on one limb of KuramBio specimen (Fig. 4F), although difficult to observe on the other mounted limb of KuramBio specimen, basis with 3 medial setae; endopod segment 1 without setae, not visible in KuramBio specimen and holotype, setal formula: $0,3,3,3,3+1$, and 4 setae.

P1 (Fig. 4H), coxa without seta; basis with very small distolateral seta, medial distal seta curved; endopod 1-segmented, lateral lobe developed, spinulated; exopod segments 1, 2, and 3 with 1 lateral spine each; lateral spine of exopod segment 1 extending to base of exopod segment 2 lateral spine, lateral spine of exopod segment 2 extending to mid-length of exopod segment 3 , lateral spine of exopod segment 3 shorter than preceding spines.
P2, exopod segments 2 and 3 broken on right leg, left leg exopod segment 3 setation abnormal, with only 2 lateral spines present (vs 3 spines typical of Clausocalanoidea), characteristics of segmentation and setation in legs are typical for family, surface spinulation absent.

P5 absent.

REMARKS. This is the first record of the genus Crassantenna in the northern part of the Pacific Ocean. The present specimen is identified as Cr. comosa. Certain features of the original description have been corrected after re-examination of the holotype although not all parts of the limbs are intact on the holotype. The minor differences from the holotype are assumed, here, to represent intraspecific variation until more specimens are examined for evidence of the extent of variability in this species.

ACKNOWLEDGEMENTS. The authors thank Prof. Angelika Brandt for providing the sorted copepod fraction of the KuramBIO expedition which contained the specimen described in this paper. The research of E.L. Markhaseva at the German Center for Marine Biodiversity Research (DZMB) was funded by a stipendium of the Research Institute Senckenberg.

\section{References}

Alvarez M.P.J. 1986. New calanoid copepods (Aetideidae) of the genera Comantenna, Mesocomantenna, new genus, and Paracomantenna off the Brazilian coast // Journal of Crustacean Biology. Vol.6. P.858-877.

Bradford J.M. 1969. New genera and species of the benthic calanoid copepods from the New Zealand slope // New Zealand Journal of Marine and Freshwater Research. Vol.3. P.473505 .

Bradford J.M., Jillett J.B. 1980. The marine fauna of New Zealand: Pelagic calanoid copepods: family Aetideidae // New Zealand Oceanographic Institute Memoir. Vol.86. 102p.

Cole R., Green M., Howcroft J., Rawlins K. 1972. Crustacea // The Zoological Record. Vol.106. Section 10. Pt.1. 213 p.

Ferrari F.D., Ivanenko K. 2008. The identity of protopodal segments and the ramus of maxilla 2 of copepods (Copepoda) // Crustaceana. Vol.81. P.823-835.

Giesbrecht W. 1893. Systematik und Faunistik der pelagischen Copepoden des Golfes von Neapel und der angrenzenden Meeres Abschnitte // Fauna und Flora des Golfes von Neapel. Bd.19. S. $1-831$.

Grice G.D., Hülsemann K. 1970. New species of Bottom-Living Calanoid Copepods Collected in Deepwater by the DSRV Alvin // Bulletin of the Museum of Comparative Zoology. Vol.139. P.185-227.

Huys R., Boxshall G.A. 1991. Copepod Evolution. London: The Ray Society. 468 p.

Markhaseva E.L. 1996. Calanoid copepods of the family Aetideidae of the world ocean // Proceedings of the Zoological Institute RAS. St. Petersburg. Vol.268. 331p.

Markhaseva E.L., Ferrari F.D. 2006. New benthopelagic bradfordian calanoids (Crustacea: Copepoda) from the Pacific Ocean with comments on generic relationships // Invertebrate Zoology. Vol.2 (for 2005). No.2. P.111-168.

Markhaseva E.L., Laakmann S., Renz J. 2014. An interim synopsis of the Bradfordian families with a description of Thoxancalanus spinatus (Copepoda, Calanoida), a new diaixid genus and species from the deep Atlantic Ocean // Marine Biodiversity. Vol.44. P.63-88. 
Ohtsuka S., Boxshall G.A., Shimomura M. 2005. Three new species of deep-sea hyperbenthic Aetideid copepods (Crustacea) collected from Nansei Islands, southwestern Japan // K. Hasegawa, G. Shinohara and M. Takeda (eds.). Deep-Sea Fauna and Pollutants in Nansei Islands. National Science Museum Monographs, 29. P.225-247.

Sars G.O. 1902. An Account of the Crustacea of Norway, with short descriptions and figures of all the species. Copepoda Calanoida // Bergen Museum. Vol.4. P.29-144.

Schulz K. 2002. A new species of the hyperbenthic copepod genus Comantenna Wilson, 1924 (Calanoida, Aetideidae) from the eastern Weddell Sea // Mitteilungen aus dem Hamburgischen Zooologischen Museum und Institut. Vol.99. P.101-107.

Vervoort W. 1952. Copepoda. Sub-order: Calanoida. Family: Aetideidae. Genera: Bradyidius, Bradyetes, Bryaxis // Fiches d'Identification du Zooplancton, Conseil International pour l'Exploration de la Mer. Vol.43.P. 1-4.

Wilson C.B. 1924. New North American parasitic copepods, new hosts and notes on copepod nomenclature // Proceedings of the United States National Museum. Vol.64. No.17. P.1-22.

Responsible editor K.G. Mikhailov 